\title{
Developing Design Criteria for Sustainable Urban Parks
}

* Dr. Didem Dizdaroğlu $\mathbb{P}$ p

Department of Urban Design and Landscape Architecture, Faculty of Art, Design, and Architecture, Bilkent University, Turkey

E-mail: dizdaroglu@bilkent.edu.tr

\section{ARTICLE INFO:}

\section{Article History:}

Received: 28 February 2021

Revised: 15 August 2021

Accepted: 19 August 2021

Available online: 30 August 2021

\section{Keywords:}

Sustainable Cities;

Urban Parks;

Green Spaces;

COVID-19;

Sustainable Design.

\section{ABSTRACT}

5i) Check For

This study investigates how urban parks can contribute to helping cities become more sustainable through developing a set of criteria for the sustainable design of urban parks. Today, there is no example around the world where all the proposed sustainable design criteria are applied together in a specific urban park. In this context, this study aims to make a novel contribution by systematically reviewing the literature on the sustainable design of urban parks. In the light of research findings, this study contributes to the implementation of a comprehensive sustainable park design practice in our cities in the future. These design criteria may further serve as performance indicators to offer information and know-how to local authorities, practitioners, communities, and other actors in this field to help them assess their success levels and progress over time.

\footnotetext{
This article is an open access

article distributed under the terms and conditions of the Creative Commons Attribution (CC BY) license

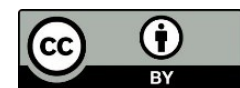

This article is published with open access at www.ijcua.com
}

JOURNAL OF CONTEMPORARY URBAN AFFAIRS (2022), 6 (1), 69-81.

https://doi.org/10.25034/ijcua.2022.v6n1-7

Www.ijcua.com

Copyright @ 2021 by Dr. Didem Dizdaroğlu.

\section{Introduction}

Globalization and the ever-growing population have been a threat to resource sustainability since the 1950s, as these two factors have introduced drastic changes in the structure of ecosystems and their services. Wasting renewable resources, causing climate change, and producing pollution now more than ever, humans have gone way beyond the Earth's carrying capacity. United Nations Sustainable Development Goals Report (2020) suggests that higher than 39 million people have now been affected by climate change, facing the consequences like disrupted livelihoods, economic losses, and even death. The report indicates that one-fifth of the Earth's surface area (over 2 billion hectares) is now degraded lands. The acidification in oceans is expected to increase up to $100-150 \%$ by the

*Corresponding Author:

Department of Urban Design and Landscape Architecture,

Faculty of Art, Design, and Architecture, Bilkent

University, Turkey

Email address: dizdaroglu@bilkent.edu.tr 
end of this century, and accordingly, half of the entire marine life will be affected. The annual deforestation rate was estimated to be 10 million hectares between the years 2015 and 2020. Over the last three decades, the risk of extinction for species has deteriorated by approximately $10 \%$. The alarming decrease of the world's forest areas continues at an unprecedented rate, and several species face the threat of extinction.

The COVID-19 outbreak imposed several negative impacts on the progress of Sustainable Development Goals (SDGs). The estimates indicate that the pandemic exacerbated poverty and hunger due to labour losses and food shortages during the worldwide lockdowns (Sachs et al., 2020). The pandemic has shown the importance of urban planning in improving public health and reducing the public's vulnerability to other threats like natural disasters. Preventing infection and arresting the spread of the virus necessitate taking urgent actions to improve access to water, sanitation, and hygiene services. Long-term mobility plans should be put into effect for improving access to public transport systems well-integrated with walking and cycling networks. Demand for open public areas increases even further with cities on lockdown. As the outbreak progresses, urban administrations are required to put new policies and strategies into practice to manage and alleviate the heightened risk of COVID-19 transmission and reconstruct resilient and sustainable cities in a post-COVID-19 environment.

Urban green spaces have begun gaining renewed attention during the COVID-19 pandemic. As has been confirmed by several studies so far, the COVID-19 pandemic has urged people to reconsider the significance of urban green spaces (Rice and Pan, 2020; Hockings et al., 2020; Ugolini et al., 2020; Samuelsson et al., 2020). According to the study carried out by Derks et al. (2020), the number of visits made to forests during the lockdowns in Germany has seen an incredible increase. A study conducted by Geng et al. (2021) has focused on analysing the effects produced by the epidemic and the policies made by governments to manage the outbreak in terms of park visits on global, national, and regional scales. Results of this study indicated that the number of visits made to parks had gone up since February 16, 2020, compared to the number of visits paid to parks before the outbreak. The increase in park visits correlates with the constraints imposed on social events, gatherings, social mobility, the closing of workplaces, and indoor places where recreational activities are carried out. A study conducted by Grima et al. (2020) has focused on evaluating the significance of urban and peri-urban forests, woodlands, and various other natural locations for urbanites and suburbanites of Burlington, Vermont, USA. These areas were substantial for the people for a great variety of recreational activities, including exercising, bonding with nature, finding tranquillity and quiet, walking dogs, spending time with children, and bird watching. Accordingly, this takes us to the critical point; the significance of urban parks for maintaining a healthy urban environment is on the rise for people of all ages.

Urban parks, offering several environmental, economic, and social advantages, serve various purposes in the city. They are a valuable resource in designing sustainable cities. This research aims to investigate how urban parks can contribute to helping cities become more sustainable. The aim of this research is supported by the following research objectives: (1) defining a sustainable city and its design principles; (2) outlining the role of urban parks as part of the green infrastructure of the city, and; (3) establishing a set of criteria for the sustainable design of urban parks. For this purpose, a systematic literature review has been performed in this study. As illustrated in Figure 1, the steps for conducting a systematic literature review consist of: (1) formulating the research aim and objectives; (2) searching databases for literature; (3) evaluating the selected relevant studies; (4) analysing and synthesising the findings, and; (5) writing the research results. This paper consists of four sections: The background and introduction to the study are provided in Section 1. The research methodology is introduced in Section 2. Moreover, the concept of sustainability and sustainable development, along with the design of a sustainable city, is disclosed in this section. Section 3 outlines the sustainable design criteria of urban parks in addition to the environmental, social, and economic benefits thereof. In conclusion, a summary and some concluding statements are provided in Section 4. 


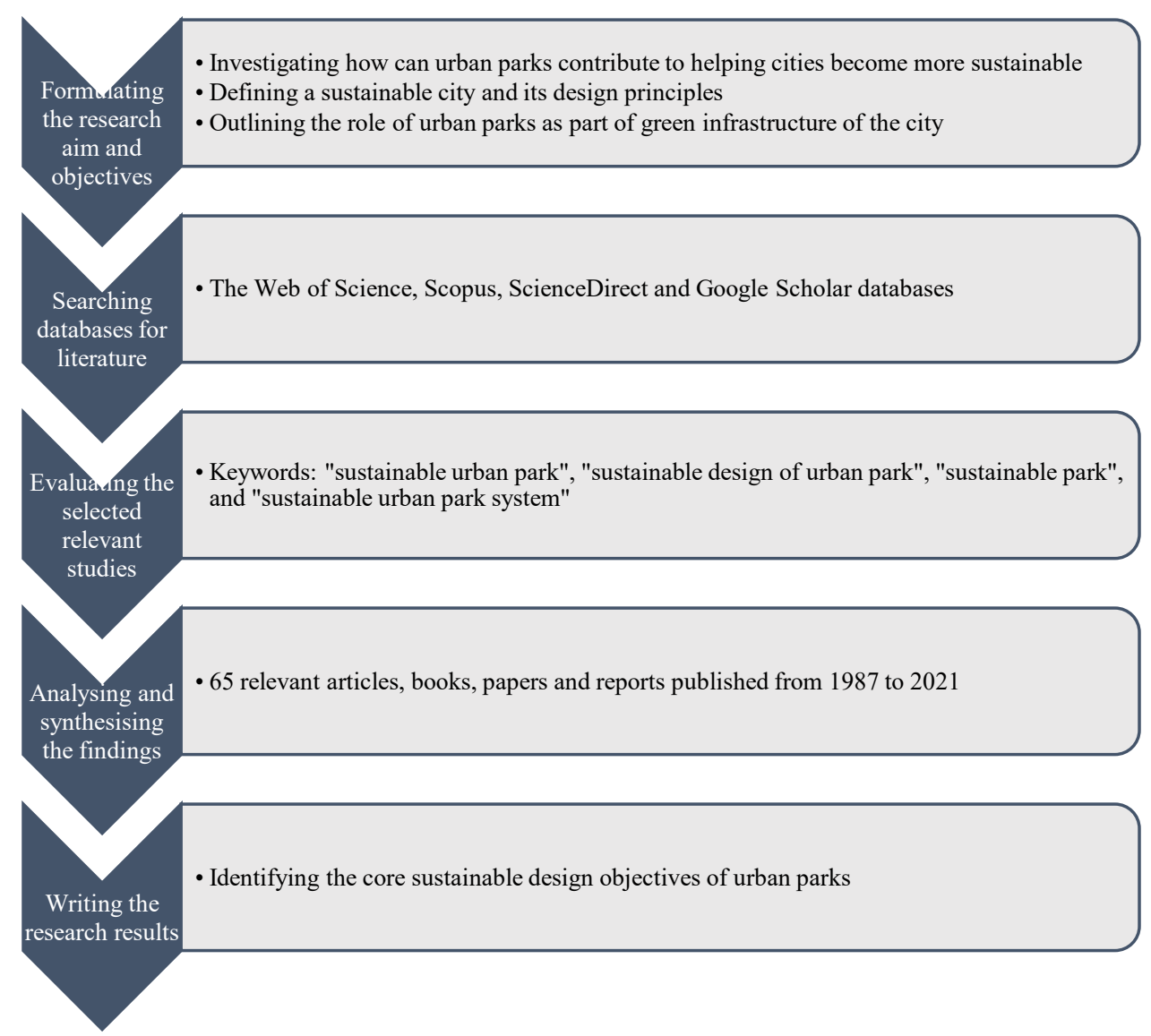

Figure 1. Methodology of the Research.

\section{Materials and Methods}

In this study, a systematic literature review was carried out to identify and develop sustainable design criteria for urban parks. The literature on sustainable urban parks was reviewed extensively during the development process of the design criteria based on international literature review and analysis of "grey" literature. The Web of Science, Scopus, ScienceDirect, and Google Scholar databases were utilized for searching published and peerreviewed literature. Keywords like "sustainable urban park", "sustainable design of urban park", "sustainable park", and "sustainable urban park system" were used for the searches conducted in the literature. Sixty-five relevant articles, books, papers, and reports published from 1987 to 2021 were selected using these keywords.
Additionally, to devise the search criteria, ten core sustainable design objectives of urban parks were defined, which are: (1) providing the green infrastructure; (2) creating a place for people of all ages; (3) building connected park systems within walking distance, (4) implementing water and energy conservation practices; (5) waste management; (6) promoting access to fresh, healthy, and lowcost food; (7) supporting and preserving biodiversity, (8) environmental education and stewardship through hands-on activities; (9) ensuring the long-term maintenance and management of the park, and; (10) supporting disaster resilience.

\subsection{The Concept of Sustainability and Sustainable Development}

Sustainability, as a concept, emerged in the early 1970s as an answer to concerns growing about the impact of urban development on resource use. In the book "The Ecology of Commerce: A Declaration of Sustainability" (1993, p.139), Paul Hawken expresses sustainability as a manifesto to overcome 
destructive human actions: "Leave the world better than you found it, take no more than you need, try not to harm life or the environment, make compensations if you do". In 1972, The United Nations Stockholm Conference on the Human Environment, having issued a declaration to emphasize concerns about environmental protection on an international scale, sparked a debate on the concept of sustainability. The United Nations, to develop a global agenda on resource conservation, formed the World Commission on Environment and Development in 1983. The commission issued a Brundtland report, and the term 'sustainable development' was first introduced in the report Our Common Future (WCED, 1987, p.43): "Development that meets the needs of the present without compromising the ability of future generations to meet their own needs". The United Nations Conference on Environment and Development also went as Rio Earth Summit, which was organized in 1992. Agenda 21, having been set forth as a result of the Rio Conference, provided an action scheme for sustainable development. The World Summit on Sustainable Development was organized in Johannesburg in 2002 to evaluate the ground covered since the Rio Conference witnessed several discussions on the global difficulties encountered in connection with the preservation of natural resources, poverty eradication, sustainable consumption, and development of a productive and healthy life.

Since then, there has been a considerable amount of research conducted to identify sustainable development. Girardet (2004, p.6) modified the Brundtland Commission definition of sustainable development: "A city that enables all its citizens to meet their own needs and to improve their well-being, without degrading the natural planet or the lives of other people, now or in the future". A more comprehensive definition is developed by Roosa (2010, p.44): "Sustainable development is the ability of physical development and environmental impacts to endure long term habitation on the planet Earth by human and other indigenous species while providing: (1) an opportunity for environmentally safe, ecologically appropriate physical development; (2) efficient use of natural resources; (3) a framework which allows improvement of the human condition and equal opportunity for current and future generations, and; (4) manageable urban growth". Moreover, there are many descriptions of sustainable development exist in the literature (Wheeler and Beatley, 2004; Baker and Eckerberg, 2008; Clini et al., 2008; Ukaga et al., 2010; Weinstein and Turner, 2012; Sachs, 2015; Brever et al., 2019; Dalby et al., 2019; Idowu et al., 2020).

The 2030 Agenda for Sustainable Development issued in 2015 introduced 17 goals and 169 targets to achieve worldwide sustainable development by 2030 (United Nations, 2015). From eliminating poverty and hunger to improving education and health, and reducing inequality, and combating climate change, 17 Sustainable Development Goals comprise a large spectrum of issues. The aim of Goal 11: "Sustainable Cities and Communities" among these Sustainable Development Goals is to make cities and human settlements more inclusive, secure, resilient, and sustainable. Goal 11 consists of 10 targets: (1) providing everyone access to sufficient, secure, and accessible housing and essential services; (2) providing everyone gain access to secure, accessible, affordable and sustainable transportation systems; (3) enhancing comprehensive and sustainable urban development and capacity for participative and integrated planning; (4) fortifying efforts for protecting and safeguarding cultural and natural heritage; (5) providing resilience against natural disasters; (6) minimizing urbanization's impact on the environment; (7) offering universal access to secure, comprehensive, and accessible public green spaces; (8) promoting constructive economic, social, and environmental bonds between rural, peri-urban and urban areas; (9) pursuing and carrying out integrated policies and plans for inclusion, the efficacy of resources, alleviation of climate change, and; (10) providing financial and technical support for the purpose of constructing sustainable and resilient buildings.

\subsection{Designing a Sustainable City}

Over the past few years, several cities have started pilot projects to implement sustainable practices and policies such as BedZED (Beddington Zero Energy Development), London; Bo01, Malmö; Christie Walk EcoVillage Project, Adelaide; Hammarby Sjöstad, Stockholm; Model City (MoMa), Mannheim; 
ZAC De Bonne, Grenoble; Vauban, Freiburg, and Lombok, Utrecht. Furthermore, many rating tools have been introduced, such as SITES (Sustainable Sites Initiative), LEED (Leadership in Energy and Environmental Design), STAR (Sustainability Tools for Assessment and Rating System), BREEAM (Building Research Establishment Environmental Assessment Method), CASBEE (Comprehensive Assessment System for Building Environmental Efficiency), Green Globes and Green Star to address environmental issues on various geographical scales and track progress towards SDGs. From the examples given above, numerous different sets of principles have been developed to guide the sustainable design of a city. According to ICLEI Local Governments for Sustainability (2021), a sustainable city is defined as: "building a city with an ecologically, socially and economically healthy as well as resilient habitat for existing populations, without bargaining the ability of future generations to experience the same". Even though the sustainable city has been identified with different criteria and prominences by many scholars (Jenks and Dempsey, 2005; Newman and Jennings, 2008; Blanco \& Mazmanian, 2015; Gardner et al., 2016; Bishop, 2017; Cohen, 2018; Wang et al., 2019), its primary goal is to promote and facilitate the long-term well-being of people and the planet, through effective use of natural resources and management of wastes while enhancing liveability through economic prosperity and social well-being within a city (Newman, 1999).

Designing sustainable cities comprises four extensive policy areas, including ecological integrity, social well-being, economic welfare, and good governance (United Nations, 2013). In this context, ecological integrity implies safeguarding biological diversity and conserving fundamental processes of ecology and systems of life support. Social well-being indicates enhancing the welfare of citizens through social impartiality, namely, providing complete access to utilities, including education, healthcare services, transportation, housing, and recreational activities. Economic welfare involves effectively distributing resources, goods, and services to provide for the needs of people living in the present and potential communities. Good governance implies consolidating democratic institutions at every level to ensure transparency and responsibility in terms of governance and inclusionary participation in making decisions (Dizdaroglu, 2017). It is possible to outline the strategies for designing sustainable cities under the main titles as given below:

Sustainable urban design aims to ensure that natural processes that support life stay intact and keep working along with initiatives aspiring after enhancing individual life quality and public welfare.

Sustainable transportation refers to the capability of meeting society's needs for mobility with minimal damage to both the environment and to the mobility needs of the next generations.

Sustainable use and supervision of natural resources aim to minimize the overall waste generation by employing waste prevention initiatives, ensuring improved resource efficiency, and promoting the shift to more sustainable patterns in production and consumption.

A socially inclusive community is one in which all members of the community are accepted, their differences are acknowledged, and their fundamental needs are fulfilled so that they can live in dignity.

A sustainable economy can offer the best opportunities for general well-being by utilizing the least number of resources and causing the least possible harm to the environment.

Educating for sustainable development is a strategy that intends to prepare and improve students, schools, and societies under the ideals and inspiration serving as an impetus to conduct people to behave in favour of sustainability in their personal lives and communities, and on a global scale, both now and in the future.

\section{Developing Design Criteria for Sustainable Urban Parks}

In the struggle against climate change and degradation of the environment, the concept of green infrastructure comes into importance as a crucial solution. Urban parks, an essential component of green infrastructure and predominantly covered by vegetation are identified as both public and private open areas encouraging active or passive recreational and sports activities or indirectly creating a positive impact on the urban environment accessible by citizens (BaycanLevent et al., 2003). Urban parks make 
significant contributions to sustainable city designs by providing a range of environmental, social, and economic benefits. In terms of environmental benefits, urban parks offer cooler ambient temperatures compared to surrounding areas. Since pollutant emissions are generally associated with ambient temperatures (e.g., evaporation of volatile organic compounds), cooler ambient temperatures may help reducing pollutant emissions. Urban parks that offer conditions similar to forests are capable of improving carbon storage in time as the net amount of carbon can build up in the soil together with carbon reserved in trees. Additionally, urban parks make contributions to the management of stormwater with an emphasis on increased rates of water runoff in green urban spaces relative to other uses of urban lands. Urban parks have a significant influence on reducing noise. They have the capability of reducing environmental health risks stemming from urban life (Brown and Grant, 2005; Pauleit et al., 2005; Brown et al., 2015; Yan et al., 2018; Aram et al., 2019). Furthermore, urban parks are crucial for maintaining biodiversity in cities. As reported by several researchers, urban parks may serve as especially valuable hotspots for maintaining biodiversity in the urban landscape as they feature high habitat diversity levels as much as microhabitat heterogeneity (Öckinger et al., 2009; CarboRamirez and Zuria, 2011; Tonietto et al., 2011; Oishi, 2012; Ksiazek et al., 2014; Parris et al., 2018; Filazzola et al., 2019; Wenzel et al., 2020; Turo, 2021).

When it comes to social benefits, urban parks create a positive effect on both physical and mental health as they encourage and increase physical activity, reduce stress, anxiety, depression in addition to improving selfrespect, cognitive functions, and social behaviours of positive nature (Kaplan, 2001; Cohen at al., 2007; Akbar et al., 2010; Lee at al., 2011; Ward Thompson et al., 2012; Sandifer et al., 2015; Wood et al., 2017; Birch et al., 2020). Rather than being seen as an environment for recreation and relaxation, urban parks are considered an integral aspect of the development of a community. An urban park environment shared by various social and ethnic backgrounds may offer the citizens the opportunity to bond and communicate (Chiesura, 2004; Maas et al., 2009; Peters et al., 2010; Arnberger and Eder, 2012; Moulay et al.,
2017). Moreover, urban parks serve as an education platform. Education on the environment advances citizens' knowledge and enhances their perception as much as their behaviour for creating a resilient environment and community. Urban parks are excellent for first-hand learning experiences. Next generations, having acquired knowledge and skills with the implementation of environmental conservation practices, will be encouraged and inspired as a result of helping children bond with nature through naturebased approaches (Varela-Candamio et al., 2018). With regards to economic benefits, urban parks render a city more attractive and make it a popular destination for tourists, thereby creating employment and generating revenue. Additionally, urban parks not only increase the value of real estate properties in close proximity but also improve tax revenues (Troy and Grove, 2008; Hoshino and Kuriyama, 2010; Bark et al., 2011).

The sustainable design of urban parks is one of the most successful approaches in addressing the environmental problems of urban spaces. According to Hermy (2011), sustainable urban park design, which in practice should require adapting to local conditions, utilizing natural processes, the continuation of park monitoring, and knowledge on the management of recreation, is the long-term maintenance of diverse ecosystems to ensure that they keep fulfilling their various roles in the future. Accordingly, the definition of a sustainable urban park should correspond to a place in which natural resources are preserved, wildlife habitat is further improved, and built such that it does not affect the ecosystem while serving people's leisure needs. In view of this definition, it may be concluded that a sustainable urban park promotes sustainable planning and management practices in the creation of a self-resilient landscape that utilizes the least amount of energy and that can respond to ever-changing circumstances. Urban parks have an important place in the minimization of adverse effects on the environment by; (1) providing green alternatives in transportation reducing carbon footprint; (2) enhancing the quality of air by means of increasing tree canopy; (3) decreasing power demand and landfill waste; (4) providing the green structure necessary for reducing stormwater runoff and flooding; (5) taking up natural resource management practices, thereby protecting 
watersheds, and; (6) promoting sustainability through public engagement and education activities. Several strategies may be followed for planning a sustainable urban park (Figure 2):

- Providing the green infrastructure: Urban parks play an essential part in the improvement of a city's capability of adapting to extreme weather conditions alongside the impacts of climate change. Green infrastructure, necessary for resiliency to climate change, is provided by urban parks. The integration of the green structure into urban parks can create a variety of benefits, including lower surface temperatures, well-managed stormwater runoff, better air quality, new habitats for the local native fauna, and improved environmental health. Planting rain gardens accommodating native or adapted species, building bioswales, bioretention ponds, constructed wetlands, installing rainwater cisterns, and employing water permeable pavers are great examples of green infrastructure practices for urban park environments.

- Creating a place for people of all ages: Urban parks play an essential role in establishing a sense of community and social belonging. Bringing life to green spaces requires year-round utilization and events oriented toward individuals of all genders, cultures, and skills. Urban parks that are diverse, socially inclusive, accessible to everybody, and welcoming to all people of all ages and interests require an annual schedule consisting of various events and activities. Promoting physical activities for individuals of all ages and abilities, offering a wide variety of facilities (e.g., water fountains, clean, hygienic, and secure restrooms, informative signs), and designing comfortable sitting areas will result in a park that is capable of catering for everyone.

- Building connected park systems within walking distance: A well-designed system of urban parks provide citizens with secure, convenient, and efficient ways to get to and enjoy the parks. There is a variety of solutions that can be implemented to improve a park's connectivity and accessibility, such as creating a properly designed network of interconnected streets capable of accommodating walking pedestrians as well as cyclists, adopting strategies calming the traffic, providing a range of entry points to the park, and upgrading the park's entrances.

- Implementing water and energy conservation practices: Urban parks make significant contributions to water conservation. These contributions include but are not limited to; (1) providing support to the utilization of greywater and rainwater harvesting systems; (2) establishing smart irrigation systems (3); selecting water-wise plants; (4) utilizing water-permeable landscape materials; and (5) introducing green roofs and water features that are eco-friendly. Urban parks also contribute to energy conservation by means of; (1) promoting the utilization of renewable energy in the construction of urban lighting and furniture, (2) establishing sitting areas to enhance thermal comfort, and; (3) utilizing light-coloured solar-reflective roofing and paving materials.

- Waste management: Urban parks may also function as centres for recycling, allowing for composting of the solid waste created in the park. In addition, urban parks can further save energy and decrease the emission of greenhouse gasses by producing urban furniture, pavements, and walls from recycled materials.

- Promoting access to fresh, healthy, and lowcost food: Urban agriculture may be incorporated into urban park systems within the scope of the local and sustainable food production by utilizing community gardens with the aim of enhancing the nourishment and well-being of humans while also fostering social networks, education, and comprehension with regards to food.

- Supporting and preserving biodiversity: Urban Park systems accommodate the wildlife and flora by serving as a habitat. Performing the respective landscaping activities in consideration of the native plants provides a range of advantages. Native flora needs less upkeep as they are already adapted to the conditions of the local environment, are disease and insectresistant and attract pollen carriers and accommodate wildlife. The emission of urban lights may be diminished during the night with the aim of preserving wildlife's migratory and breeding habits. To promote environmental interactions within an urban park, habitat steppingstones may be 
created for the wildlife. Variation of the flora for food and shelter, birth baths, fountains and pools, nesting boxes, rocks, brush, and log piles, as well as bee walls and insect hotels are all among the recommended interventions for the habitat. Putting policies and regulations for preserving biodiversity offers security on various levels for safeguarding endangered and under threat species.

- Environmental education and stewardship through hands-on activities: Urban parks are the perfect locations for improving the residents' bond with nature and advancing their knowledge, comprehension, and appreciation of nature. Education on the environment advances citizens' knowledge and enhances their perception as much as their behaviour for creating a resilient environment and community. For instance, education on environment and guidance programs may include; (1) urban park activity programs like walks in nature and exercising programs outdoors; (2) voluntary works allow citizens to participate in routine activities and maintenance like cleaning, mowing grass, and planting; (3) educational school trips, after school activities, outdoor events on a seasonal basis for both the youth and children, and; (4) therapeutic landscapes and healing gardens for individuals who are challenged emotionally, physically, and mentally.

- Ensuring the long-term maintenance and management of the park: Management of an urban park is not limited to maintenance performed on a periodic basis. The first step to be taken in this regard is to adopt an integral and comprehensive point of view with respect to the definition of an urban park and the duties that the park staff should perform. This involves taking a strategic look at the available assets, deciding on the way these assets can be linked to the community and the way of finding new opportunities that may potentially promote engagement. One point to emphasize in this regard is that an area's residents and other stakeholders should be encouraged to participate and get involved both in the process and after making important decisions and introducing major changes. Efficient management of urban parks requires creating sustainable, inclusive community stewardship through forming partnerships between urban parks and local boards of trade, societies, local businesses, community centers, and other social institutions. Furthermore, non-profit groups that consist of people who are sincerely concerned about urban parks may campaign for introducing changes, plan fundraisers and special activities and events.

- Supporting disaster resilience: Urban parks should be designed to serve a variety of functions in consideration of emergencies to provide places for gathering, provisional shelters, food, water, waste management, radio broadcasting, and power. In addition to acting as self-contained centres, urban parks should also serve as part of a vast network that incorporates alternative connections and essential facilities like hospitals and emergency services. 


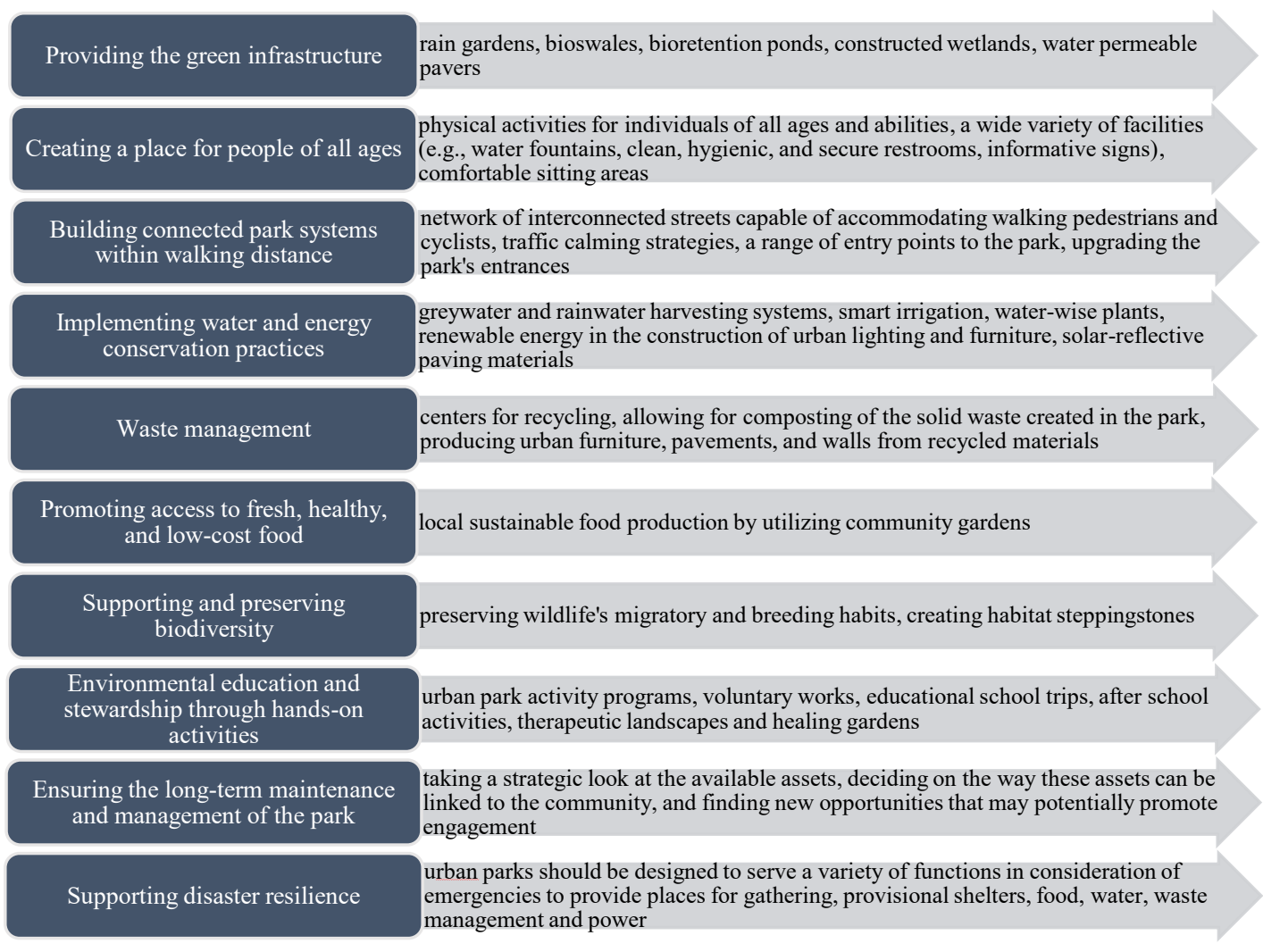

Figure 2. Ten Core Sustainable Design Objectives of Urban Parks.

\section{Conclusion}

Extending the scope of the role assumed by urban parks as a component of the city's green infrastructure with the aim of overcoming difficulties in urban areas stemming from anthropogenic factors, sustainable urban parks have been a growing trend in recent decades. Sustainable urban park designs have been adopted and put into practice by many local governments. For instance, the New York City Department of Parks and Recreation published a 'Plan for Sustainable Practices within New York City Parks' with the aim of alleviating the city's impact on the environment by means of; (1) adopting sustainable practices in all the stages of urban park development; (2) establishing collection areas for recycling in order to provide assistance with effective waste management; (3) improving composting efficiency for leaves in urban parks; (4) creating sustainable landscape design; (5) creating a communicative bond between the employees of urban parks and citizens with education and outreach programs on education, and; (6) establishing indicators for sustainability with the aim of evaluating progress and focusing on strengths and areas require improvement. The City of Sacramento Department of Parks and
Recreation initiated a 'Sustainability Plan' that focuses on nine specific areas, namely, climate protection, air quality, material resources, urban design, land use, green building \& transportation, public health \& nutrition, parks, open space \& habitat conservation, energy conservation, water resources \& flood protection and public involvement \& personal responsibility along with goals and targets associated with the foregoing. The Pennsylvania Department of Conservation and Natural Resources published 'Creating Sustainable Community Parks and Landscapes Guidebook' to describe the way of maintaining urban parks in a sustainable manner and offer step-by-step instructions with the aim of assisting park employees to achieve programmed results. A number of other examples in this regard include 'Developing Sustainable Park Systems in Oregon' by the Oregon Parks and Recreation Department, 'Sustainability Plan: A City within a Park' by the Westerville Parks and Recreation Department, 'Sustainable Parks Initiatives' by the Minneapolis Park and Recreation Board, 'Sustainability Plan' by the Washington State Parks, etc.

The COVID-19 outbreak that has still yet to be beaten around the world has prompted 
countries to introduce drastic measures for social distancing with the aim of arresting the spread of COVID-19. However, these measures and the pressure of social distancing caused loneliness, anxiety, and depression to increase, especially for the people who inhabit heavily populated urban areas with few accessible open areas. Several epidemiologic studies evaluated the effects of the COVID-19 pandemic on mental health and found out that frequent visits to urban parks during the pandemic are related to decreased levels of depression, stress, and anxiety (Heo et al., 2021). It is obvious that spending time in urban parks helps to deal with the negative physical and psychological health effects caused by natural disasters and pandemics. The ongoing COVID-19 outbreak has brought to light the vitalness of built-up green spaces as a core component of life quality in the design phase of sustainable cities.

Adopting and implementing sustainable practices in the design process of urban parks offer an important opportunity for overcoming a variety of environmental issues, including the preservation of nature, biodiversity, and wildlife, alleviation of the impacts of climate change, development of community life, and the reduction of the excessive usage of natural resources. Today, there is no example around the world where all the proposed sustainable design criteria are applied together in a specific urban park. In this context, this study aims to make a novel contribution by systematically reviewing the literature on the sustainable design of urban parks. In the light of research findings, this study contributes to the implementation of a comprehensive sustainable park design practice in our cities in the future. Design criteria proposed in this study may form a basis for converting urban parks into sustainable green spaces by promoting potential improvements for plans of future development. These design criteria may further serve as performance indicators to offer information and know-how to local authorities, practitioners, communities, and other actors in this field to help them assess their success levels and progress over time.

Overall, rapid urbanization imposed significant burdens on public infrastructures like public transport systems and utility facilities. Rapid urbanization also created an ecosystem that is immensely stressed and strained. The continuing mutual action between climate change and rapid urbanization also introduces further complications into the situation. It poses a key threat to the global natural environment, economic prosperity, social security, and wellbeing of humans. Urban settlements are the areas where the impacts imposed by humans on the climate are the most extensive, persevering, and focused due to carrying the weight of heavily clustered population and economic properties. Consequently, it is widely accepted that proper planning of green areas in urban settlements is vital to ensuring a sustainable future. Integration of sustainability practices into the design process of urban parks is now far more important than ever before to make sure that our cities are more resilient to climate, assuring a better and healthier future for our communities.

\section{Acknowledgements}

This research did not receive any specific grant from funding agencies in the public, commercial, or not-for-profit sectors.

\section{Conflict of interests}

The author declares no conflict of interest.

\section{References}

Akbar, M., Mustafa Kamal, M. S., Mariapan, M., Maulan, S., \& Sheybani, M. (2010). The role of urban green spaces in mood change. Australian Journal of Basic and Applied Sciences, 4(10), 5352-5361.

Aram F., Solgi E., Higueras García E., Mosavi A., \& R. Várkonyi-Kóczy A. (2019). The cooling effect of large-scale urban parks on surrounding area thermal comfort. Energies, 12(20), 3904. https://doi.org/10.3390/en12203904

Arnberger, A., \& Eder, R. (2012). The influence of green space on community attachment of urban and suburban residents. Urban Forestry \& Urban Greening. $\quad 11(1), \quad 41-49$. https://doi.org/10.1016/j.ufug.2011.11.003

Baker S., \& Eckerberg K. (Ed.) (2008). In pursuit of sustainable development: new governance practices at the sub-national level in Europe. Routledge: $\quad$ London. https://doi.org/10.4324/9780203928165

Bark, R. H., Osgood, D. E., Colby, B. G., \& Halper, E. B. (2011). How do homebuyers value different types of green space? Journal of Agricultural and Resource Economics, 36(2), 395-415. Retrieved 
April 9, 2021, from https://www.jstor.org/stable/23243088

Baycan-Levent, T., van Leeuwen, E., Rodenburg, C., \& Nijkamp, P. (2003). Development and management of green spaces in European cities: a comparative analysis. In E. Beriatos \& J. Colman (Eds.), The Pulsar Effect in Urban Planning (pp. 237247). Volos, Greece: ISOCARP Congress Publications and University of Thessaly Press.

Birch J., Rishbeth C., \& Payne S. R. (2020). Nature doesn't judge you - how urban nature supports young people's mental health and wellbeing in a diverse UK city. Health \& Place, 62, 102296. https://doi.org/10.1016/j.healthplace.2020.102296

Bishop, J. (2017). Building sustainable cities of the future. Springer, Cham. https://doi.org/10.1007/978-3-319-54458-8

Blanco, H., \& Mazmanian, D. A. (Ed.) (2015). Elgar companion to sustainable cities: strategies, methods and outlook. UK: Edward Elgar. https://doi.org/10.4337/9780857939999

Brown, C., \& Grant, M. (2005). Biodiversity and human health: what role for nature in healthy urban planning? Built Environment, 31(4), 326-338. https://doi.org/10.2148/benv.2005.31.4.326

Brown, R. D., Vanos, J., Kenny, N., \& Lenzholzer, S. (2015). Designing urban parks that ameliorate the effects of climate change. Landscape and Urban Planning, 138, 118-131. https://doi.org/10.1016/j.landurbplan.2015.02.006

Carbó-Ramírez, P., \& Zuria, I., (2011). The value of small urban greenspaces for birds in a Mexican city. Landscape and Urban Planning, 100(3), 213-222. https://doi.org/10.1016/j.landurbplan.2010.12.008

Chiesura, A. (2004). The role of parks for the sustainable city. Landscape and Urban Planning, 68(1), 129138.

https://doi.org/10.1016/j.landurbplan.2003.08.003

Clini, C., Musu, I., \& Gullino, M. L. (Ed.) (2008). Sustainable development and environmental management experiences and case studies, Springer, Dordrecht, the Netherlands. https://doi.org/10.1007/978-1-4020-6598-9

Cohen, D. A., Mckenzie, T. L., Sehgal, A., Williamson, S., Golinelli, D., \& Lurie, N. (2007). Contribution of public parks to physical activity. American Journal of Public Health, 97(3), 509-514. https://doi.org/10.2105/AJPH.2005.072447
Cohen, S. (2018). The sustainable city. Columbia University

Press. https://doi.org/10.7312/cohe18204

Dalby, S., Horton, S., Mahon, R. and Thomaz, D. (Ed.) (2019). Achieving the sustainable development goals global governance challenges. Routledge, London. https://doi.org/10.4324/9780429029622

Derks J., Giessen L., \& Winkel G. (2020). COVID-19induced visitor boom reveals the importance of forests as critical infrastructure. Forest Policy and Economics, $\quad 118, \quad 102253$ https://doi.org/10.1016/i.forpol.2020.102253

Dizdaroglu, D. (2017). The Role of Indicator-Based Sustainability Assessment in Policy and the Decision-Making Process: A Review and Outlook, Sustainability, $\quad 9(6), \quad 1018$. https://doi.org/10.3390/su9061018

Filazzola, A., Shrestha, N., MacIvor, J. S., \& Stanley, M. (2019). The contribution of constructed green infrastructure to urban biodiversity: a synthesis and meta-analysis. Journal of Applied Ecology, 56(9), 2131-2143. https://doi.org/10.1111/1365$\underline{2664.13475}$

Gardner, G., Prugh, T., \& Renner, M. (Ed.) (2016). Can a city be sustainable? state of the world. Washington: Worldwatch Institute.

Geng, D., Innes, J., Wu, W., \& Wang, G. (2021). Impacts of COVID-19 pandemic on urban park visitation: a global analysis. Journal of Forestry Research, 32 (2), 553-567. https://doi.org/10.1007/s11676-02001249-W

Girardet, H. (2004). Cities people planet: liveable cities for a sustainable world. Academy Press. https://doi.org/10.1093/oso/9780199264520.003.0 $\underline{011}$

Grima N., Corcoran W., Hill-James C., Langton B., Sommer H., \& Fisher B. (2020). The importance of urban natural areas and urban ecosystem services during the COVID-19 pandemic. PLOS ONE, 15(12), $\mathrm{e} 0243344$ https://doi.org/10.1371/journal.pone.0243344

Hawken, P. (1993). The ecology of commerce: how business can save the planet. Weidenfeld and Nicolson.

Heo, S., Desai, M.U., Lowe, S.R., \& Bell, M.L. (2021). Impact of Changed Use of Greenspace during COVID-19 Pandemic on Depression and Anxiety. International Journal of Environmental Research 
and Public Health, 18, 5842. https://doi.org/10.3390/ijerph18115842

Hermy, M. (2011). Landscaped parks and open spaces. In I. Douglas, D. Goode, M. Houck, R. Wang (Eds.), The Routledge Handbook of Urban Ecology (pp. 289-300). Routledge, London. https://doi.org/10.4324/9780203839263

Hockings M., Dudley N., Elliott W., Ferreira M. N., Mackinnon K., Pasha M. K. S. et al. (2020). Editorial essay: Covid-19 and protected and conserved areas. Parks 26(1), 7-24. https://doi.org/10.2305/IUCN.CH.2020.PARKS26-1MH.en

Hoshino, T., \& Kuriyama, K. (2010). Measuring the benefits of neighbourhood park amenities: Application and comparison of spatial hedonic approaches. Environmental \& Resource Economics, 45, 429-444. https://doi.org/10.1007/s10640-009-9321-5

ICLEI Local Governments for Sustainability (2021). Sustainable city. Retrieved April 9, 2021, from https://e-lib.iclei.org/wpcontent/uploads/2016/10/ICLEI-Brochure Sept2016_Final.pdf

Idowu, S. O., Schmidpeter, R., \& Zu, L. (Ed.) (2020). The future of the UN sustainable development goals: business perspectives for global development in 2030. Springer. https://doi.org/10.1007/978-3-030-21154-7

Jenks, M., \& Dempsey, N. (Ed.) (2005). Future forms and design for sustainable cities. Routledge, London. https://doi.org/10.4324/9780080455525

Kaplan, R. (2001). The nature of the view from home: psychological benefits. Environment and Behavior, 33(4), 507-542. https://doi.org/10.1177/00139160121973115

Ksiazek, K., Tonietto, R., \& Ascher, J. S. (2014). Ten bee species new to green roofs in the Chicago area. The Great Lakes Entomologist, 47(1), 87-92. Retrieved April 9, 2021, from https://scholar.valpo.edu/tgle/vol47/iss1/13

Lee, A. C. K., \& Maheswaran, R., (2011). The health benefits of urban green spaces: a review of the evidence. Journal of Public Health, 33(2), 212-222. https://doi.org/10.1093/pubmed/fdq068

Maas, J., van Dillen, S. M. E., Verheij, R. A., Groenewegen, P. P. (2009). Social contacts as a possible mechanism behind the relation between green space and health. Health \& Place, 15(2), 586-
595.

https://doi.org/10.1016/j.healthplace.2008.09.006

Moulay A., Ujang N., \& Said I. (2017). Legibility of neighborhood parks as a predicator for enhanced social interaction towards social sustainability. Cities, 61, 58-64. https://doi.org/10.1016/j.cities.2016.11.007

Newman P., \& Jennings, I. (2008). Cities as sustainable ecosystems: principles and practices. Island Press, Washington DC.

Newman, P. W. G. (1999). Sustainability and cities: extending the metabolism model. Landscape and Urban Planning, 44(4), 219-226. https://doi.org/10.1016/S0169-2046(99)00009-2

Öckinger, E., Dannestam, A., \& Smith, H. G., (2009). The importance of fragmentation and habitat quality of urban grasslands for butterfly diversity. Landscape and Urban Planning, 93(1), 31-37. https://doi.org/10.1016/j.landurbplan.2009.05.021

Oishi, Y. (2012). Influence of urban green spaces on the conservation of bryophyte diversity: The special role of Japanese gardens. Landscape and Urban Planning, 106(1), 6-11. https://doi.org/10.1016/j.landurbplan.2011.12.001

Parris, K. M., Amati, M., Bekessy, S. A., Dagenais, D., Fryd, O., Hahs, A. K., ... Williams, N. S. G. (2018). The seven lamps of planning for biodiversity in the city. Cities, 83, 44-53. https://doi.org/10.1016/j.cities.2018.06.007

Pauleit, S., Ennos, R., \& Golding, Y. (2005). Modeling the environmental impacts of urban land use and land cover change - a study in Merseyside, UK. Landscape and Urban Planning, 71(2-4), 295-310. https://doi.org/10.1016/j.landurbplan.2004.03.009

Peters, K., Elands, B., \& Buijs, A. (2010). Social interactions in urban parks: stimulating social cohesion?. Urban Forestry \& Urban Greening, 9(2), 93-100. https://doi.org/10.1016/j.ufug.2009.11.003

Rice W. L., \& Pan B. (2020). Understanding drivers of change in park visitation during the COVID-19 pandemic: a spatial application of big data. SocArXiv. https://doi.org/10.31235/osf.io/97qa4

Roosa, S. A. (2010). Sustainable development handbook. The Fairmont Press, Inc.

Sachs, J. D. (2015). The age of sustainable development. New York, NY: Columbia University Press. https://doi.org/10.7312/sach17314 
Sachs, J., Schmidt-Traub, G., Kroll, C., Lafortune, G., Fuller, G., \& Woelm, F. (2020). The sustainable development goals and covid-19: sustainable development report 2020. Cambridge: Cambridge University

Press. https://doi.org/10.1017/9781108992411

Samuelsson K., Barthel S., Colding J., Macassa G., \& Giusti M. (2020). Urban nature as a source of resilience during social distancing amidst the coronavirus pandemic. OSF Preprints 3wx5a, Center for Open Science. https://doi.org/10.31219/osf.io/3wx5a

Sandifer P. A., Sutton-Grier A. E., \& Ward B. P. (2015). Exploring connections among nature, biodiversity, ecosystem services, and human health and wellbeing: opportunities to enhance health and biodiversity conservation, Ecosystem Services, 12, 1-15. https://doi.org/10.1016/j.ecoser.2014.12.007

Tonietto, R., Fant, J., Ascher, J., Ellis, K., \& Larkin, D., (2011). A comparison of bee communities of Chicago green roofs, parks and prairies. Landscape and Urban Planning, 103(1), 102-108. https://doi.org/10.1016/j.landurbplan.2011.07.004

Troy, A., \& Grove, J. M. (2008). Property values, parks, and crime: a hedonic analysis in Baltimore, MD. Landscape and Urban Planning, 87(3), 233-245. https://doi.org/10.1016/j.landurbplan.2008.06.005

Turo, K. J., Spring M. R., Sivakoff, F. S., Delgado de la flor, Y. A., \& Gardiner, M. M. (2021). Conservation in post-industrial cities: how does vacant land management and landscape configuration influence urban bees?. Journal of Applied Ecology, 58(1), 58-69. https://doi.org/10.1111/1365-2664.13773

Ugolini, F., Massetti, L., Calaza-Martínez, P., Cariñanos, P., Dobbs, C., Ostoic, S. K. et al. (2020). Effects of the COVID-19 pandemic on the use and perceptions of urbangreen space: an international exploratory study. Urban Forestry and Urban Greening, $\quad 56, \quad 126888$. https://doi.org/10.1016/j.ufug.2020.126888

Ukaga, O., Maser, C., \& Reichenbach, M. (Ed.) (2010). Sustainable development: principles, frameworks, and case studies. Boca Raton: CRC Press. https://doi.org/10.1201/9781439820636
Varela-Candamio L., Novo-Corti I., \& Garcia-Alvarez M. T. (2018). The importance of environmental education in the determinants of green behavior: A meta-analysis approach. Journal of Cleaner Production, $170,1565-1578$. https://doi.org/10.1016/j.jclepro.2017.09.214

Wang, M. H., Ho, Y. S., \& Fu, H. Z. (2019). Global performance and development on sustainable city based on natural science and social science research: A bibliometric analysis. Science of the Total Environment, 666, 1245-1254, https://doi.org/10.1016/j.scitotenv.2019.02.139

Ward Thompson, C., Roe, J., Aspinall, P., Mitchell, R., Clow, A., \& Miller, D. (2012). More green space is linked to less stress in deprived communities: evidence from salivary cortisol patterns. Landscape and Urban Planning, 105(3), 221-229. https://doi.org/10.1016/j.landurbplan.2011.12.015

WCED (1987). Our Common Future (The Brundtland report), World Commission on Environment and Development, New York: Oxford University Press.

Weinstein, M. P., \& Turner, R. E. (Ed.) (2012). Sustainability science: the emerging paradigm and the urban environment, Springer. https://doi.org/10.1007/978-1-4614-3188-6

Wenzel A., Grass I., Belavadi V. V., Tscharntke T. (2020). How urbanization is driving pollinator diversity and pollination - a systematic review. Biological Conservation, 241, 108321. https://doi.org/10.1016/j.biocon.2019.108321

Wheeler, S. M., \& Beatley, T. (Ed.) (2004). Sustainable urban development reader. Routledge. https://doi.org/10.4324/9780203501627

Wood L., Hooper P., Foster S., \& Bull F. (2017). Public green spaces and positive mental health investigating the relationship between access, quantity and types of parks and mental wellbeing. Health and Place, 48, 63-71. https://doi.org/10.1016/j.healthplace.2017.09.002

Yan, H., Wu, F., \& Dong, L. (2018). Influence of a large urban park on the local urban thermal environment. The Science of the total environment, 622-623, 882891.

https://doi.org/10.1016/j.scitotenv.2017.11.327 